\title{
REJECTION OF EXECUTORY CONTRACTS IN BANKRUPTCY AND REORGANIZATION
}

\author{
LEe Silverstein†
}

$T^{N}$ THE law of secured commercial transactions, one of the hazards with which a seller or lender must reckon is the possible rejection of the debtor's executory contracts by the trustee in bankruptcy or reorganization.

Unfortunately, the law on certain aspects of the power of rejection is by no means clear. Despite the fact that the power has been recognized since at least $1794,{ }^{1}$ neither the courts nor the learned writers ${ }^{2}$ have developed a clear and consistent rationale for its exercise. The courts have usually been content to allow or disallow the exercise of the power without exploring its underlying policy basis or bases. The purpose of this article is to examine the cases and statutes on the power of rejection so that a consistent and practical theory of the power may be stated. This approach requires both a historical review of the subject and a comparison of the present English and American law. Proposals for amendment of the American law will be made at appropriate places.

The trustee's power of rejection in straight bankruptcy is provided in section 70b of the Bankruptcy Act, ${ }^{3}$ which was first adopted in 1938. Analogous provisions for reorganizations and arrangements appear in other sections of the act. ${ }^{4}$ It is generally recognized that all the provisions

$\dagger$ Research attorney, American Bar Foundation. The opinions expressed are the author's and do not necessarily represent the views of the American Bar Foundation.

1 Bourdillon v. Dalton, I Esp. 233, 170 Eng. Rep. 340 (1794).

2 The fullest discussion is in 4 CoLlier, BANRruptcx $\$ \$ 70.43-70.44$ (14th ed. 1942, Supp. 1959). Others are 2 REMINGTON, BANKRUPTCY $\$ \S 852.095,1141.75$ (5th ed. 1956); Gottesman, The Onus of Executory Contracts in Bankruptcy: Focus on Vendors and Lessors, Prac. Law., Apr. 1958, p. 65; Roeder, Landlords, Bankruptcy, and 77B, 23 CoRNell L.Q. 285 (1988); Stanley, Leasehold Rights in Bankruptcy and Equity Proceedings, 29 KY. L.J. 301 (1941).

352 Stat. 879 (1938), as amended, 11 U.S.C. $\& 110($ b) (Supp. IV, 1963). Former § 70b, a part of the Bankruptcy Act of 1898, 30 Stat. 562, dealt with a different subject.

4 Railroads: § 77(b), 47 Stat. 1474 (1933), as amended, 11 U.S.C. \$ 205(b) (1958).

Corporate reorganizations under ch. X: $\$ \S 116(1), 216(4), 52$ Stat. 885, 895 (1938), 11 U.S.C. $\$ \$ 516(1), 616(4)$ (1958). These provisions are derived from former $\$ 77 \mathrm{~B}(\mathrm{~b})(6)$, 48 Stat. 912 (1934).

Arrangements under ch. XI: §§ 313(1), 357(2), 52 Stat. 906, 910 (1938), II U.S.C. §§ 718(1), 757(2) (1958).

Real estate arrangements under ch. XII: $\S \S 413(1), 461(4), 52$ Stat. 917, 921 (1938), 11 U.S.C. §§ 813(1), 861(4) (1958).

Wage earners' plans under ch. XIII: $\S \S 613(1), 646(6), 52$ Stat. 931, 934 (1938), 11 U.S.C. $\$ \S 1013(1), 1046(6)$ (1958). 
are largely declaratory of pre-existing case law..$^{5}$ Comparable provisions are found in the bankruptcy statutes of England and other common-law countries and in the commercial codes of civil-law countries.

The power of rejection is an anomaly to contract or property law. Instead of getting what he bargained for, the disappointed obligee has only a right to file a claim for damages for breach and to share in such dividend as there may be after payment of administration expense, wages, taxes and rent. Where the insolvent debtor is a lessor, his trustee can reject the lease only to a very. limited extent, as explained in section III hereafter. But to this limited extent the commercial lessee is subject to uncertainty as to the future.

The power of rejection is a valuable weapon, however, in the armory of the trustee in protecting the rights of creditors. As such it complements his power to undo other kinds of transactions and obligations, namely preferences, fraudulent conveyances, or liens obtained by legal or equitable proceedings within a prescribed time prior to bankruptcy.

Inevitably these two attitudes are at war with one another. ${ }^{6}$ The contract or property interest demands enforcement of the original transaction whereas the bankruptcy interest demands cancellation of the bankrupt's obligations, thus freeing his estate to pay a larger dividend to general creditors. By and large the English and Continental law favor the contract or property interest, the American law the bankruptcy interest. In public utility cases, such as a railroad reorganization, a third interest comes on the field-the public interest.

\section{Historical Background}

The history of the power of rejection helps explain the law as it stands today. The earliest reported case is a Lord Mansfield decision in $1794,{ }^{7}$ but the opinion indicates that the power of rejection was already

5 House Comm. ON the Judiciary, 74th Cong., 2d Sess., ANalysis of H. R. 12889, 227 (Comm. Print 1936); Weinstein, The Bankruptcy LAw of 1998, A Comparative Analysis Prepared for the National Assoclatyon of Credit Men 159-60 (1938); Gleick, Rent Claims and Security Deposits in Bankruptcy, 18 Mo. L. Rev. 1, 9 (1953), also appearing in 58 CoM. L.J. 181, 184 (1953), 27 REF. J. 43, 44 (1953); McLaughlin, Amendment of the Bankruptcy Act, 40 HARv. L. Rev. 583, 605-06 (1927); Rickles, Claims Arising From Breach of Executory Contracts, 26 REF. J. 21 (1952).

6 Cf. Melville, Disclaimer of Contracts in Bankruptcy, 15 Mod. L. REv. 28 (1952), who points out that there is a "conflict between the principle that a trustee shall respect existing rights and the policy that, in the administration of an insolvent estate, there should be a power to throw off onerous liabilities so as to prevent one creditor being paid in full where others have to be content with a dividend . . . ."

7 Bourdillon v. Dalton, 1 Esp. 233, 170 Eng. Rep. 340 (1794). Lord Mansfield said that an assignee in bankruptcy may not be charged with rent unless he has taken possession, and if he chooses to abandon the premises as burdensome to the estate, the lease may not be forced upon him. 
familiar at that time. The power almost certainly originated in the law merchant, the international commercial law of which bankruptcy was a constituent part. During the fourteenth to sixteenth centuries when the merchants of various countries mingled at the fairs and markets, such bankruptcies as occurred were handled by the merchants themselves in pied poudre fashion. In this setting one can surmise that a practice developed of permitting a representative of the creditors to abandon worthless property of the bankrupt so as to speed up liquidation and distribution of the estate. The courts then moved from abandonment of a worthless chattel to rejection of an onerous executory contract or lease. ${ }^{8}$ Both kinds of property are a burden to the estate. By the time the first English bankruptcy act was adopted in 1542,9 the principles of bankruptcy were well established in the law merchant. English commissioners or assignees in bankruptcy were probably applying an established mercantile custom when they began using the power of rejection-or disclaimer, as it is called in England. In 1623 another bankruptcy act provided that the powers of the commissioners should be construed liberally to help creditors. ${ }^{10}$ Just as the law merchant was the source of the British bankruptcy law, so also it was the source of bankruptcy law on the Continent. Although provisions vary to some extent, the power of rejection or disclaimer is a common and necessary principle in modern legal systems. ${ }^{11}$

8 Cf. Note, Abandonment of Assets by a Trustee in Bankruptcy, 53 ColuMr. L. REv. 415 (1953), which classifies unprofitable executory contracts as a kind of property that should be abandoned. Other kinds are worthless property held by the bankrupt for sentimental reasons, property that is heavily encumbered and doubtful choses in action.

0 An Act Against Such Persons as Do Make Bankrupts, 1543, 34 \& 35 Hen. 8, c. 4. See 8 Holnsworth, History of ENGlish LAw 236 (1926). Coke makes this patriotic comment (Institutes of the Laws of England, IV, c. 63 (1628)): "We have fetched as well the name as the wickedness of bankrupts from foreign nations . . . . In former times as the name of a bankrupt, so was the offence itself (as has been said) a stranger to an Englishman, who of all other nations was freest of bankruptcy. And the first statute that we find against this crime, was indeed made against strangers, viz. against Lombards, who after they had made obligations to their creditors, suddenly escaped out of the realm without any agreement made with their creditors . . . ."

10 An Act for the Further Description of a Bankrupt, and Relief of Creditors Against such as Shall Become Bankrupts, etc., 1623, 21 Jac. 1, c. 19, § 1 . All previous bankruptcy acts were to be "in all things largely and beneficially construed and expounded" in the interest of creditors, "for that divers defects are daily found in the former statutes made against bankrupts, both in the description of a bankrupt, as also in the power given to the commissioners for the discovery and distributing of the bankrupt's estate, to the great encouragement of evil-minded persons, the hindrance of traffic and commerce ..." and other things tending "to the general hurt of this realm." The same act, $\S 7$, provided a penalty of two hours in the pillory and loss of an ear for making a fraudulent conveyance of the value of $20 £$ or more.

11 On the power of rejection, the German Code has the most detailed provisions. 
The foundation for the modern law of rejection in America was laid down in the earlier English cases. Although the first comprehensive English statute on disclaimer was not enacted until 1869,12 the Act of 1809 had dealt with one aspect of disclaimer ${ }^{13}$ and the case law had dealt with other aspects. In several cases the problem was whether the assignees had shown by their conduct that they intended to adopt a lease.14 Other cases involved the application of a statutory provision permitting a bankrupt tenant to terminate his personal liability on the lease where the assignees failed to elect to disclaim. ${ }^{15}$ Still other cases recognized the power of disclaimer in assignments for the benefit of creditors as distinguished from bankruptcy. ${ }^{16}$ In America the power made its first appearance in the state courts in the 1840's and 1850's in

Konkursordnung RGBI, 1898 Nr. 25, S. 612, §§ 17-28, translated in 24 CoMmercial LAwS OF THE WORLD 290 (Scrutton \& Bowstead eds. 1912). The Code provides that if a tenant becomes bankrupt, either the trustee or the landlord may reject the lease. If the landlord becomes bankrupt, his trustee may not reject the lease, but if the trustee sells the property the sale has the same effect as a judicial sale and the purchaser may terminate the lease. A lessee of movables, however, is entitled to retain them until the end of the period of lease notwithstanding a sale by the trustee of the lessor.

The Italian Bankruptcy Law of 1942 provides that the trustee may disaffirm only certain types of contracts, such as a contract for the sale of goods. The obligee of this kind of contract is not permitted to prove a claim, but a lessor whose lease is rejected may do so. Riesenfeld, The Evolution of Modern Bankruptcy Law, 31 MINN. L. REv. 401, 418 (1947).

The French Code has no provision as to adoption or rejection of any form of agreement except a lease of immovable property (real estate). The Code provides that the trustee of a lessee may with court permission affirm a lease. CODE DE COMMERCE, art. 450 (Fr. 50th ed. Dalloz 1954). A translation appears in 21 Commerclal LAws of THE WORLD 134 (Scrutton \& Bowstead eds. 1912). The courts by the process of decision have developed flexible administrative rules under this provision. Dalloz, Encyclopedie JURIDIQue, 2 Repertoire de Droit Commercial et des Societes \$\$ 2035-49 (Verge \& Ripert eds. 1957). Similarly, the courts have recognized a power in the trustee to adopt or reject executory contracts as distinguished from leases. The normal rule in France, however, much like that in England, is to uphold the obligation of contract insofar as possible rather than to allow rejection. Id., § 1751 . For instance, a contract provision is void that provides that bankruptcy ipso facto shall constitute a breach. Id., § 1731 .

12 An Act to Consolidate and Amend the Law of Bankruptcy, 1869, 32 \& 33 Vict., c. $71, \S 23$.

13 An Act to Alter and Amend the Laws Relating to Bankrupts, 1809, 49 Geo. 3, c. 121, $\$ 19$. This provided that if the assignees in bankruptcy should refuse to accept a lease of the bankrupt, they would be exonerated from further obligations under the lease. But the statute also gave the landlord some protection by providing a method by which he could require the assignees to make a prompt election to accept or disclaim.

14 Wheeler v. Bramah, 3 Camp. 340, 170 Eng. Rep. 1404 (K.B. 1813); Turner v. Richardson, 7 East. 335, 103 Eng. Rep. 129 (K.B. 1806); Thomas v. Pemberton, 7 Taunt. 206, 129 Eng. Rep. 83 (C.P. 1816).

15 Copeland v. Stephens, 1 Barn. \& Ald. 593, 106 Eng. Rep. 218 (K.B. 1818); Tuck v. Fyson, 6 Bing. 321, 130 Eng. Rep. 1304 (C.P. 1829).

16 Carter v. Warne, 4 Carr. \& Payne 191, 172 Eng. Rep. 665 (N.P. 1830); Clark v. Hume, 1 Ryan \& Moody 207, 171 Eng. Rep. 995 (N.P. 1825). 
a variety of kinds of insolvency. ${ }^{17}$ It was chiefly in the equity receivership cases in the federal courts, however, that the power was delineated and developed. During this formative period from 1840 to 1900, the courts apparently gave little or no thought to the question of whether the power of rejection should have different attributes in two contrasting kinds of cases: (I) Liquidation of the debtor's estate, as in bankruptcy, assignments for the benefit of creditors and liquidating receiverships; (2) continued operation and rehabilitation, as in receiverships of railroads and other public utilities. Cases of both kinds were cited indiscriminately as precedents. ${ }^{18}$ Following the enactment of the present Bankruptcy Act in 1898, the federal courts, now sitting as courts of bankruptcy, quite naturally applied the principles of rejection that they had themselves developed in the equity receivership cases. Rather sweeping powers to reject leases had been developed in the railroad receivership cases. (This remedy complemented the authority of the receiver to pray for reformation of the lease; both remedies being effective in undoing the chicanery and manipulation that sometimes characterized nineteenth-century railroad finance. ${ }^{19}$ ) But as applied to ordinary bankruptcy this turned out to be harsh. For example, the landlord was not allowed to prove damages in bankruptcy for unpaid rent falling

17 Martin v. Black, 9 Paige Ch. 641, 38 Am. Dec. 574 (N.Y. 1842) (equity receiver); Journeay v. Brackley, I Hilt. 447 (N.X. 1857) (assignment for benefit of creditors); Rugely \& Harrison v. Robinson, 19 Ala. 404 (1851) (Bankruptcy Act of 1841); Streeter v. Sumner, 31 N.H. 542 (1855) (same); Horwitz v. Davis, 16 Md. 313 (1860) (assignment for benefit of creditors); Hoyt v. Stoddard, 84 Mass. (2 Allen) 442 (1861) (assignee in insolvency); Ex parte Houghton, 12 Fed. Cas. No. 6725 (D. Mass. 1871) (the earliest federal case-Bankruptcy Act of 1867).

18 American File Co. v. Garrett, 110 U.S. 288 (1884) (bankxuptcy case citing English receivership cases); Sunflower Oil Co. v. Wilson, 142 U.S. 313 (1892) (railroad receivership case citing bankruptcy and receivership cases and a treatise on receivers); Quincy, Mo. \& Pac. R.R. v. Humphreys, 145 U.S. 82 (1892) (same); United States Trust Co. v. Wabash W. Ry., 150 U.S. 287 (1893) (same); Dushane v. Beall, 161 U.S. 513 (1896) (bankruptcy case citing previous receivership cases decided by same court as well as one English receivership case and several English bankruptcy cases). The last four cases became the leading American cases on the power of rejection. See also Stockton v. Mechanics \& Laborers Sav. Bank, 32 N.J. Eq. 163, 169 (1880): "The liability of the receiver in insolvency in such case is precisely the same as that of an assignee in insolvency or bankruptcy, who may retain or surrender the lease according as it may seem most advantageous for the estate of the debtor." Other state cases are Wells v. Hartford Manilla Co., 76 Conn. 27, 55 Atl. 599 (1903) (receivership case involving rejection of contract for purchase of paper pulp-court cites railroad lease rejection cases); New Hampshire Trust Co. v. Taggart, 68 N.H. 557, 44 Atl. 751 (1896) (case involves statutory assignee of insolvent bank-court cites bankruptcy and receivership cases); Woodruff v. Erie Ry., 93 N.Y. 609 (1883) (receivership citing 1842 New York receivership case which had relied entirely on English bankruptcy cases).

19 Cf. Grand Rapids Trust Co. v. United Light \& Power Co., 7 F. Supp. 511 (W.D. Mich. 1981); Globe Woolen Co. v. Utica Gas \& Elec. Co., 224 N.Y. 483, 491, 121 N.E. 378, 380 (1918); Comment, 33 Mich. L. REv. 631 (193I). 
due after the date of adjudication. ${ }^{20}$ This rule was altered by statute in 1934.21

The theory of the power of rejection has never really been re-examined by the courts. From 1898 until the codification of the rejection power in the amendments of 1933 to 1938,22 the courts merely elaborated on the received rules. This was partly because most of the cases involved mere administrative questions, such as how long a time the trustee should be allowed for making his election, what conduct constituted adoption of the contract or lease, and what compensation the receiver should pay a lessor for use and occupancy absent adoption of the lease. After the amendments of the 1930's most of the cases have turned on questions of statutory interpretation, often against the background of pre-existing case law. Again, with rare exceptions, the courts have not examined the theory of the power of rejection.

\section{Theory and Scope of the Power of Rejection}

What is the theory of rejection? Does the term "executory contract" have a special meaning in connection with rejection, a meaning different from that in the ordinary law of contract? What are the limitations upon the power of rejection as developed by the courts and as prescribed by statute? Is there any difference in the application of the power of rejection as between leases and other kinds of executory contracts?

The courts and writers usually state that the trustee in bankruptcy need not accept as part of the bankrupt's estate any property which is onerous or burdensome, since to do so would diminish rather than augment the estate available for distribution to creditors. ${ }^{23}$ In the older cases a typical form of onerous property was the unfavorable leasehold owned by the bankrupt lessee. By about 1890, the courts were applying

20 MacLachlan, Bankruptcy 127 (1956). For discussions of some of the difficulties under the prior law, see Douglas \& Frank, Landlords' Claims in Reorganization, 42 YALE L.J. 1003 (1933). The former federal rule still obtains in some state courts. E.g., People ex rel. Nelson v. West Town State Bank, 373 Ill. 106, 25 N.E.2d 509 (1940).

21 Bankruptcy Act $\S 4 \mathrm{a}, 48$ Stat. 923 (1934), amending the Bankruptcy Act § 63a, 30 Stat. 562 (1898).

22 See note 4 supra.

23 Dushane v. Beall, 161 U.S. 513, 515 (1896); Glenny v. Langdon, 98 U.S. 20,30 (1878); White v. Griffing, 44 Conn. 437 (1877); Streeter v. Sumner, 31 N.H. 542 (1855); BLACK, BANKRUPTCY 683 (3d ed. 1922); 4 CollIER, BANKRUPTCY 1332 (14th ed. 1942, Supp. 1959); RoBSON, BANKRUPTCY 329 (1872). Some of the older cases suggest as an additional element making for rejectability, the oppressiveness or unfairness of a contract, sometimes verging on illegality or violation of public policy, but these cases smack of rescission rather than rejection. Sunflower Oil Co. v. Wilson, 142 U.S. 313, 322, 325 (1892); Express Co. v. Railway Co., 99 U.S. 191 (1878); Ellis v. Boston, H. \& E.R.R., 107 Mass. 1 (1871); cf. Mutual Life Ins. Co. v. Smith, 184 Fed. 1 (1st Gir. 1911). See GiucK \& BeCKer, Receivers of CoRporations 316-19 (2d ed. 1896). 
the same rule to onerous choses in action. With the rise of modern methods of distribution and finance and the vast growth of intangible forms of wealth, difficult problems in the application of the power of rejection have presented themselves to the courts, problems involving executory contracts unrelated to land. At the same time problems involving leaseholds still require solution.

As Lord Ellenborough declared in an early English case,

[A]ssignees of a bankrupt are not bound to take ... property of the bankrupt, which so far from being valuable would be a charge to the creditors; but they may make their election: if, however, they elect to take the property, they cannot afterwards renounce it because it turns out to be a bad bargain . . . .4

This principle of a binding election still applies with full rigor. The converse also holds true: Once the trustee rejects a contract, he cannot afterwards adopt it. In reorganization, however, as distinguished from bankruptcy, the principle of a binding election has been modified. In both bankuptcy and receivership cases decided before the amendments of the 1930's, the trustee or receiver was allowed a reasonable time within which to make his election. ${ }^{25}$ Long periods were often permitted. Meanwhile, the other party could bring pressure on the trustee or receiver only by the cumbersome remedy of asking the court to require him to make his election.26 This unsatisfactory procedure led to the adoption in 1938 of the sixty-day provision of section $70 \mathrm{~b}$ which required a prompt election, except where the court allowed an extension of time. ${ }^{27}$ Inaction by the trustee is automatically a rejection. Thus uncertainty and delay, formerly the bane of creditors, are now kept to a minimum. In reorganization, however, the statutory provisions are less strict, and the courts have tended to interpret them in such a way as to revert to the older rule. The statute itself provides that a trustee in a chapter $\mathrm{X}$ reorganization can reject an executory contract as in straight bankruptcy;

24 Turner v. Richardson, 7 East. 335, 342, 103 Eng. Rep. 129, 132 (K.B. 1806).

25 Dushane v. Beall, 161 U.S. 513, 515 (1896); Sunflower Oil Co. v. Wilson, 142 U.S. 313, 322 (1892); Sparhawk v. Yerkes, 142 U.S. 1 (1891); Pacific W. Oil Co. v. McDuffie, 69 F.2d 208 (9th Cir. 1934); Butterworth v. Degnon Contracting Co., 214 Fed. 772 (2d Cir. 1914); In re Frazin, 183 Fed. 28 (2d Cir. 1910).

28 In Samuels v. E.F. Drew \& Co., 292 Fed. 734, 739 (2d Cir. 1923), the court recognized the hardship that this rule imposed on a seller of coconut oil, the price of which was subject to market fluctuation.

27 As adopted in 1938, § 70b provided: "Within sixty days after the adjudication, the trustee shall assume or reject any executory contract, including unexpired leases of real property: Provided, however, That the court may for cause shown extend or reduce such period of time ... Bankruptcy Act $\$ 70 \mathrm{~b}, 52$ Stat. 880 (1938). For the 1962 amended version, see note 123 infra. 
but another section says that, in addition, the plan of reorganization, which follows at a later time, may also allow for rejection of executory contracts. ${ }^{28}$ Thus it appears from reading these two sections together that the trustee has two turns at bat. ${ }^{28 a} \mathrm{He}$ may either reject promptly, as in straight bankruptcy, or may reject later as part of the plan of reorganization. In effect this either allows the trustee a very long "reasonable time" for his election, or else allows him to first assume the contract and later reject it. The courts have confirmed this interpretation by ruling that the sixty-day limit of section 70b does not apply to chapter X.29

Bankruptcy ipso facto disables the bankrupt from performing most of his contracts since he loses control of his assets. The trustee, upon his appointment and qualification, is vested by operation of law with the bankrupt's title to property as of the date the petition was filed. ${ }^{30}$ In a strict sense it may be said that the trustee should affirm or reject all the contracts of the bankrupt that he has not fully performed. Yet in practice the power of rejection is applied only to certain kinds of executory contracts.

Several different fact situations may be defined:

(1) Upon adjudication of bankruptcy, the debtor's only executory duty is to pay money for goods or services purchased on open account, and the creditor has fully performed. In this very common situation, the trustee usually does not need to reject the contract, even though it is executory on the side of the bankrupt. This is because the creditor understands when he receives his notice of the bankruptcy that the bankrupt will not be able to pay the account. To require the trustee to reject all such contracts would unduly burden him with an insignificant detail. It would also add unduly to the cost of administration of bankruptcies. Moreover, if the trustee fails to notify the creditor, he is not left in doubt for long: Under section $70 \mathrm{~b}$ the trustee must act

28 Bankruptcy Act $\S \S 116(1), 216(4), 52$ Stat. 885, 896 (1938), 11 U.S.C. $\S \S 516(1)$, 616(4) (1958). See note 4 supra, for citation to parallel sections in other chapters of the Act.

28a But see In re Davega Stores Corp., CCH BANkR. L. REP. If 60777 (S.D.N.Y. 1963). A trustee renegotiated a lease, got a lower rent in a chapter XI proceeding and had it confirmed by the court. Then when the proceeding was changed to chapter $\mathrm{X}$, the trustee tried to reject the lease. Held, rejection denied.

29 See discussion in text at notes 127-29 infra.

30 Bankruptcy Act $\S 70 a, 52$ Stat. 879 (1938), 11 U.S.C. $\S 110$ (a) (1958). A special provision governs transactions that occur after the filing of a petition but before the bankrupt has given up physical possession of the assets. Bankruptcy Act § 70d, 52 Stat. 881 (1938), 11 U.S.C. $\S 110$ (d) (1958). In England, the title of the trustee relates back to the time of the act of bankruptcy upon which a receiving order is entered against the bankrupt. Bankruptcy Act, 1914, 4 \& 5 Geo. 5, c. 59, $\S 37$. The filing of a voluntary petition is deemed an act of bankruptcy for the purpose of vesting of title in the trustee. Bankruptcy Act, 1914, 4 \& 5 Geo. 5, c. 59, § 37. 
within a specified time period, and failure to act is deemed a rejection. Furthermore, if the trustee assumed one or more such contracts without assuming them all, he would be favoring such creditors over others in violation of the Bankruptcy Act. ${ }^{31}$ Hence neither trustees nor experienced creditors think in terms of even a possible assumption of such contracts. ${ }^{32}$

(2) The contract of the bankrupt is to sell goods rather than buy them, and at the time of adjudication the other party has fully performed, as by paying in advance of delivery. If the bankrupt has sufficiently appropriated or identified the goods to the contract, ${ }^{33}$ the buyer is entitled to possession against the trustee, a right that is enforceable by a petition for reclamation if the trustee should reject. ${ }^{34}$ This result may be justified on either of two theories: (a) The goods were not the property of the bankrupt at the time of adjudication, or (b) the contract was no longer executory at that time. If the goods have not been sufficiently appropriated or identified to the contract, the buyer is not entitled to the goods as against the trustee. This is the property theory applied the opposite way. As an alternative the trustee can reject the contract as executory. Either action by the trustee-resistance of the reclamation petition or rejection of the contract-leaves the creditor to a common claim for damages for breach of contract. The trustee's decision to reject should be based on three factors: contract price, market price and the relation of the assets in the estate of the bankrupt free for common creditors to the total of the claims of common creditors. Thus, even where the market price is fifty per cent below the contract price, where there are no other assets and many outstanding claims the trustee should reject and sell the goods at market. This will bring that much additional cash into the estate. The buyer who has prepaid will still have a claim for the entire amount paid but must share with other general creditors in the proceeds of the sale. The mere circumstance that the buyer has paid in advance does not of itself entitle him to any advantage relative to other unsecured creditors. $\mathrm{He}$ has parted with cash; they have furnished goods or services; but all must share pro rata in the common calamity of the debtor's failure.

(3) If the bankrupt himself has fully performed a contract but the other party has not, the contract is usually an asset of the estate rather than a possible burden. In this category are such things as the bank-

31 Bankruptcy Act $\S 65 a$, e, 52 Stat. 875 (1938), 11 U.S.C. § 105(a), (e) (1958).

32 On the meaning of "executory" in $\$ 70 \mathrm{~b}$, compare the discussion in 4 Collier, BANKRUPTCY 1350-51 (14th ed. 1942, Supp. 1959).

33 Uniform Sales Act, §§ 15, 17; Uniform Commercial Code, § 2-501; see 2 Williston, SAles \& 258 (rev. ed. 1948).

34 See MIcGann v. Capital Sav. Bank \&. Trust Co., 117 Vt. 179, 89 A.2d 123 (1952). 
rupt's accounts receivable. The principle of rejection does not apply here because it is limited to burdensome assets. One may be tempted to deduce a general proposition that a contract may be rejected only if executory upon the part of the bankrupt and not on the part of the other party. ${ }^{35}$ But this formula will not fit all situations. For example, it will not fit the three-party arrangement where a lender finances the sale. ${ }^{36}$

(4) The bankrupt owes money and the creditor holds a security interest. If the creditor has completed performance by delivering the goods or advancing the loan funds, the contract is executory only on the side of the bankrupt. This fact situation may appear to be the same as the first, but the existence of the security interest changes the picture. If the trustee permits automatic rejection by failing to elect promptly, he may cause the estate to lose av valuable asset, e.g., a conditional sale contract that has been almost fully paid out.. ${ }^{37}$ The same thing can happen where the creditor is a lessor and the bankrupt a lessee in default. ${ }^{38}$ If the trustee should assume a conditional sale contract and later default in the payments, the creditor could of course enforce his remedies against the trustee, including reclamation of the goods. Where the unpaid balance on a conditional sale contract equals or exceeds the value of the

35 In In re Pagliaro, 99 F. Supp. 548 (S.D. Cal. 1951), aff'd sub nom. Costello v. Golden, 196 F.2d 1017 (9th Cir. 1962), the trustee argued that executory meant executory on both sides, but the court held that it meant executory only on the part of the bankrupt, citing 4 CoLIIER, BANKRUPTCY 1228-29 (14th ed. 1942).

36 See In re Italian Cook Oil Corp., 190 F.2d 994 (3d Cir. 1951).

37 In the Matter of Forgee Metal Prods., Inc., 229 F.2d 799 (3d Cir. 1956) (trustee assumed conditional sale contract but failed to notify vendor, hence vendor could reclaim the goods); In the Matter of McCormick Lumber \& Mfg. Corp., 144 F. Supp. 804 (D. Ore. 1956) (trustee did not clearly assume conditional sale contract for sawmill equipment purchased by bankrupt, but since vendor failed to seek reclamation, trustee was entitled to surplus proceeds of sale after paying off balance due vendor on the contract); In re Pagliaro, 99 F. Supp. 548 (S.D. Cal. 1951), aff'd sub nom. Costello v. Golden, 196 F.2d 1017 (9th Cir. 1952) (trustee was deemed to have rejected conditional sale contract of bankrupt vendee by failure to adopt it within the statutory period).

38 In re Northern Ind. Oil Co., 180 F.2d 669 (7th Cir. 1950) (trustee abandoned leases by failing to adopt them within statutory period); accord, In the Matter of Gravure Paper \& Board Corp., 234 F.2d 928 (3d Cir. 1956). But cf. Texas \& N.O.R.R. v. Phillips, $196 \mathrm{~F} .2 \mathrm{~d} 692$ (5th Cir. 1952) (court permitted trustee of bankrupt tenant an extension of time, apparently within sixty-day period, but landlord was not notified of the extension; trustee later adopted lease and landlord objected that trustee had previously abandoned lease by inaction, but court upheld trustee); In the Matter of Morrison-Barnhart Motors, Inc., 142 F. Supp. 845 (N.D. Ohio 1956) (although trustee of bankrupt tenant failed to adopt lease within sixty days, court held he had not intended to abandon it, hence landlord who sold the premises within the sixty-day period without notifying court or trustee must pay the trustee surplus funds previously deposited by tenant with landlord as security for rent). 
property being purchased, the trustee should reject it. The secured creditor then files a petition to reclaim the property from the estate, or repossesses it in pais. ${ }^{39}$ If the property does not satisfy his claim, he also files as an unsecured creditor for the balance. Sometimes the trustee will accomplish the same result by petitioning to abandon the liened property as having no value to the estate.

The rejection power cannot be used to wipe out a security interest. In a reorganization suit where the trustee was seeking to reject the security agreement rather than the debtor's duties under an executory contract, the court denied rejection, stating that the contract was not executory. ${ }^{40}$ It is better to say that the power of rejection may not be used to destroy an otherwise valid security interest. ${ }^{41} \mathrm{~A}$ security interest may in proper cases be attacked as a preference ${ }^{42}$ or a fraudulent con-

39 In the Matter of Forgee Metal Prods., Inc., 229 F.2d 779 (3d Cir. 1956); In the Matter of McCormick Lumber \& Mfg. Corp., 144 F. Supp. 804 (D. Ore. 1956); In re Pagliaro, 99 F. Supp. 548 (S.D. Cal. 1951), affd sub nom. Costello v. Golden, 196 F.2d 1017 (9th Cir. 1952). See generally 5A ReMington, BANkRuptcy ch. 36, pt. 5 (5th ed. 1953); Collier, Bankruptcy Manual If 70.24 (5th ed. 1962).

40 In re H. K. Porter Co., 24 F. Supp. 766 (W.D. Pa. 1938) (trustee in $\$ 77 \mathrm{~B}$ reorganization sought to reject debtor's assignment to lessor of future rents of sublessees as additional security for debtor's payment of rent under head lease). Contra, United Elec. Sec. Co. v. Louisiana Elec. Light Co., 71 Fed. 615 (E.D. La. 1896), aff'd sub nom. General Elec. Co. v. Whitney, 74 Fed. 664 (5th Cir. 1896) (court permitted receiver of power company to reject contract assigning future proceeds of sale of power; court said assignment contract was executory). But cf. In re Italian Cook Oil Corp., 190 F.2d 994 (3d Cir. 1951) (trustees in ch. X reorganization petitioned to reject debtor's assignment to bank of expected proceeds from contract to sell mayonnaise; at time of petition, trustees had gone ahead with manufacture and delivery of mayonnaise, hence court ruled that this amounted to assumption of assignment contract); In the Matter of Swindle, 188 F. Supp. 601 (D. Ore. 1960) (trustee petitioned to adopt contract for purchase of real estate without adoption of subsequent modification of escrow terms requiring additional payment; court ruled trustee must adopt contract in entirety or not at all).

41 Compare the special provisions that have been inserted in the corporate reorganization sections of the Bankruptcy Act to permit repossession by the lessor or conditional vendor of railroad rolling stock and equipment, 49 Stat. 911 (1936), 11 U.S.C. $\S 205(\mathrm{j})$ (1958), or by the conditional vendor of commercial airplanes, $71 \mathrm{Stat} .617$ (1957), 11 U.S.C. \& 516(5) (1958). The latter provision does not apply to chattel mortgages. See Adkins \& Billyou, Developments in Commercial Aircraft Equipment Financing, 13 Bus. LAw. 199, 208-12 (1958).

42 Bankruptcy Act $\S 60,52$ Stat. 869 (1938), 11 U.S.C. $\S 96$ (1958). The power of rejection relates to prospective future performance, whereas the power to avoid a preference, a fraudulent conveyance, or a lien obtained by legal or equitable proceedings usually relates to transactions or events that are faits accomplis at the time of adjudication. The trustee uses the power of reject on to preserve assets that pass to him upon adjudication by rejecting burdensome executory contracts that would impair these assets. He uses the other powers to recover for the estate assets that have previously been transferred or subjected to liens. 
veyance ${ }^{43}$ but not as a burdensome executory contract. The shielding of secured creditors from rejection is justified because unsecured creditors have notice of the lien through recordation or filing.

A possible exception to the foregoing discussion is the executory contract for the sale of real estate where the vendee deposits money with the vendor before the latter is adjudicated bankrupt. In this situation, the vendee, absent bankruptcy, has an enforceable equitable lien on the land, at least if the contract provides that a lien is created and if the contract is then recorded.44 In England the lien is enforceable against the trustee in bankruptcy, ${ }^{45}$ the remedy being either specific performance of the contract or a refund of the amount paid. There is some American support for this view. ${ }^{46}$ But the federal court for the Southern District of New York has ruled that the vendee's remedy is limited to a refund of the amount paid, with no right of specific performance.47 Perhaps these opposing views can best be reconciled by a compromise rule. In cases of unusual hardship on the vendee, as where no comparable real estate is obtainable, the court could deny rejection on condition that the vendee agree to a higher purchase price. This kind of order would operate on the same principle as readjustment of an executory lease as proposed in section III, infra. One may ask why the vendee of realty should be treated better than the vendee of personalty. The answer is that real property is unique but personalty usually is not-and if it is, the realty rule should apply.

(5) The power of rejection does not apply to money or property held by the bankrupt in escrow or trust for another party, even though the escrow or trust agreement may be partly executory at the time of bankruptcy..$^{48}$ This is because the property held in escrow or trust is

43 Bankruptcy Act $\S \S 67,70 c$, e, 52 Stat. 875, 881, 882 (1938), II U.S.C. $\S \S 107$, 110 (c), (e) (1958). See MACLACHLAN, BANKRUPTCY ch. 21 (1956).

44 If the vendee fails to protect himself in this way, and if the vendor mingles the cash deposit with other funds so that the proceeds cannot be traced, the vendee is reduced to the status of a common creditor. Compare text at note 48 infra.

45 In re Bastable, [1901] 2 K.B. 518 (C.A.); Pearce v. Bastable's Trustee, [1901] 2 Ch. 122; cf. Ex parte Holthausen, L.R. 9 Ch. 722, 726 (1874).

46 Lathrop v. Specht, 186 Iowa 225, 172 N.W. 296 (1919) (assignment for benefit of creditors-strong dictum); Note, Effect of Bankruptcy on Realty Contracts, 6 Texas L. REv. 358 (1928).

47 Matter of New York Investors Mut. Group, Inc., 143 F. Supp. 51 (S.D.N.X. 1956); cf. In re Philadelphia Penn Worsted Co., 278 F.2d 661 (3d Cir. 1960) (trustee could reject because under Pennsylvania law, a contract for sale of land is executory until deed is delivered; query, whether "executory" should have same meaning in bankruptcy law as in general contract law); Central Trust Co. v. East Tenn. Land Co., 79 Fed. 19 (E.D. Tenn. 1897) (specific performance denied in equity receivership case).

48 Gulf Petroleum, S. A. v. Collazo, 316 F.2d 257 (1st Cir. 1963); American Serv. Co. v. Henderson, 120 F.2d 525, 531 (4th Cir. 1941). 
regarded as belonging to the other party. If money held in escrow is commingled with other assets, so that it can no longer be traced, the depositor is reduced to the status of a common creditor. ${ }^{49}$

(6) Can a debtor reject a floating lien held by a creditor? No cases have been found on this point. As to chattels or receivables to which the lien has already attached at the time of adjudication, the contract should be non-rejectable, for the reasons advanced in discussing the fourth hypothetical situation. As to chattels or receivables to which the lien has not attached at that time, it would seem that the lien is cut off by the trustee's prior lien under section $70 \mathrm{c}$, hence the contract need not be rejected. Firms that lend on this kind of security usually protect themselves by advancing funds only when their lien is perfected, so the problem is not likely to arise often. Conceivably, in a reorganization a trustee might affirm such a security contract and continue to use this method of financing.

(7) A lessee bankrupt's unexpired lease may be rejected as an executory contract. Indeed, history shows that the unexpired lease is the archetype of the rejectable contract. Moreover, section $70 \mathrm{~b}$ refers specifically to unexpired leases. If the trustee fails to act promptly and unequivocally, his inaction may be construed as failure to assume a favorable lease, ${ }^{50}$ since inaction constitutes rejection.

Where the lessor rather than the lessee is in bankruptcy, section 70b permits rejection but provides that it "shall not deprive the lessee of his estate." This limitation on the power of rejection is explored in section III hereafter. Leases are compared with other executory contracts at the end of the present section.

(8) The contract, other than a secured transaction, that calls for continuing performance upon both sides is more important in reorganizations than in straight bankruptcies. Examples are contracts for the development of a shopping center, ${ }^{51}$ the manufacture of goods for order, ${ }^{52}$ the purchase of goods, ${ }^{53}$ the carriage of freight by rail ${ }^{54}$ or cargo

49 Gulf Petroleum, S. A. v. Collazo, 316 F.2d 257 (1st Cir. 1963).

50 See cases cited note 38 supra.

51 Workman v. Harrison, 282 F.2d 693 (10th Cir. 1960).

52 Brandenburg v. Coxe, 228 Pa. 212, 77 Atl. 455 (1910); Harrigan v. Gilchrist, 121 Wis. 127, 99 N.W. 909 (1904).

53 Pacific W. Oil Co. v. McDuffie, 69 F.2d 208 (9th Cir. 1934); Samuels v. E.F. Drew \&: Co., 286 Fed. 278 (S.D.N.Y. 1922), aff'd, 292 Fed. 734 (2d Cir. 1923); Menke v. Willcox, 275 Fed. 57 (S.D.N.Y. 1021); Wells v. Hartford Manilla Co., 76 Conn. 27, 55 Atl. 599 (1903); cf. In re M \& S Amusement Enterprises, Inc., 122 F. Supp. 364 (D. Del. 1954) (trustee in reorganization of open-air movie corporation rejected unfavorable concession contract with candy vending company).

54 Express Co. v. Railway Co., 99 U.S. 191 (1878); Ellis v. Boston, H. \& E.R.R., 107 Mass. 1 (1871). 
by water, ${ }^{55}$ or the supplying of electric power. ${ }^{56}$ The trustee in reorganization has a reasonable time to decide whether to adopt or reject the contract. ${ }^{57} \mathrm{He}$ is under a duty to perform a contract that is favorable to the estate. 58

The power of rejection is coordinated with the principal purpose of a reorganization proceeding-rehabilitation and continued operation of the debtor. If the trustee accepts the benefits of such a contract, then seeks to reject it after the other party has fully performed, rejection will be denied..$^{59}$ An election to adopt the contract is imputed to the trustee. If, however, the contract is one requiring continuing performance on both sides, such as those mentioned above, the trustee in reorganization might originally affirm the contract, but upon finding it burdensome later, reject it then as part of the plan of reorganization. ${ }^{60}$

(9) The bankrupt licensee of a patent, copyright or trademark usually has an executory duty to pay royalties and the licensor has an executory duty not to license other persons. Although one might suppose that a trustee in bankruptcy can reject such a contract since it is executory on both sides, the American cases most nearly in point have implied that it is not rejectable. The leading case is In re Waterson, Berlin o Snyder Co.61 In this case a composer assigned to a publishing house the

55 Butterworth v. Degnon Contracting Co., 214 Fed. 772 (2d Cir. 1914); In re Rochester Shipbuilding Corp., 32 F. Supp. 98 (W.D.N.Y. 1940).

56 Consolidated Gas, Elec. Light \& Power Co. v. United Rys. \& Elec. Co., 85 F.2d 799 (4th Cir. 1936), cert. denied, 300 U.S. 663 (1937).

57 See text accompanying notes 25-29 supra.

58 Butterworth v. Degnon Contracting Co., 214 Fed. 772 (2d Cir. 1914); Harrigan v. Gilchrist, 121 Wis. 127, 352-53, 99 N.W. 909, 978 (1904); In re Great Cobar, Ltd., [1915] 1 Ch. 682; In re Newdigate Colliery, Ltd., [1912] 1 Ch. 468; In re Thames Ironworks, Shipbuilding \& Eng'r Co., [1912] Weekly N. 56. See Note, Abandonment of Assets by a Trustee in Bankruptcy, 53 Colum. L. Rev. 415, 418 (1953). Compare the rule of business judgment established by the Supreme Court in railroad reorganization cases. Group of Institutional Investors v. Chicago, M., St. P. \& Pac. R.R., 318 U.S. 523, 549-51 (1943). See note 135 infra.

59 In re Italian Cook Oil Corp., 190 F.2d 994 (3d Cir. 1951) (see note 40 supra); Spencer v. World's Columbian Exposition, 163 III. 117, 45 N.E. 250 (1896) (receiver who operated clambake concession thereby adopted lease); In re San Francisco Bay Exposition, 50 F. Supp. 344 (N.D. Cal. 1943) (receiver of insolvent building and loan association attempted to reject contract to subscribe funds to Exposition, which was itself in ch. XI arrangement; court declared that contract was not executory because Exposition had fully performed its side of contract: "Granted the power to disaffirm, it amounts to a breach and gives rise to the right to recover damages on the part of the injured party; since the measure of damages for failure to pay money is equal to the amount that should have been paid, the right of disaffirmance is illusory. ... I conclude that this is not the type of executory contract, which is subject to disaffirmance under the statute." Id. at 347).

60 See text accompanying notes $28-29$ supra.

6148 F.2d 704 (2d Cir. 1931); 45 HARv. L. REv. 586 (1932). See Chafee, Equitable Servitudes on Chattels, 41 HARv. L. REv. 945 (1928). 
right to copyright his composition and market it in exchange for payment of royalties. Upon the bankruptcy of the publisher the composer sought to rescind the contract since the publisher could no longer perform, while the trustee sought to sell the copyright free and clear of the bankrupt's duty to pay royalties. This was in effect an attempt to reject the contract. The court ruled that the composer was entitled to an equitable lien but not to the more generous remedy of rescission. Thus the trustee was required to sell the copyright subject to the agreement or servitude to pay royalties. The same rule has been applied in cases involving patented fountain pens ${ }^{62}$ and phonograph records, ${ }^{63}$ a copyrighted law book, ${ }^{64}$ and the trade mark and good will of soap products. ${ }^{65}$ Cases might arise from the licensing of the right to show old movies on television. ${ }^{66}$ And where a trustee sold patented electric razors and parts, the licensor was held to be entitled to prove a claim against the estate for infringement; moreover, this claim was recognized as an administration expense, entitled to first priority. ${ }^{67}$ Although the power of rejection as such was not discussed in these cases, to recognize the right of the author or inventor to royalties is to deny the trustee's power of rejection. If the agreement between the copyright owner and the debtor constitutes an assignment, it must be recorded to be effective against the trustee's lien under section 70c.68 Here the recordation is notice of the assignor's ownership of intangible personal property in the debtor's possession, as is recordation in real property law. Hence, if the recordation is timely, the assignor has a status similar to that of a secured creditor as in the fourth hypothetical. But suppose the assignment is merely of the right to obtain a copyright, as in the Waterson case, or suppose it is an agreement that does not ordinarily require recordation. May the trustee use his power to reject under section $70 \mathrm{~b}$, or his power as a lienholder under section $70 \mathrm{c}$, or both, to take possession of the assignor's interest, thereby relegating him to a mere claim against the estate for damages?

\section{In re S. Spitzel \& Co., 168 Fed. 156 (E.D.N.Y. 1909).}

63 Kenyon v. Automatic Instrument Co., 160 F.2d 878 (6th Cir. 1947) (where receiver of insolvent corporation sold patents that corporation held as licensee, court declared purchaser liable to licensor's survivor for value of use of patents).

64 In re Law Book Co., 239 App. Div. 363, 267 N.Y.S. 169 (1933) (assignment for benefit of creditors); $c f$. Berry v. Hoffman, 125 Pa. Super. 261, 189 Atl. 516 (1987).

65 In re Tidy House Prods. Co., 79 F. Supp. 674 (S.D. Iowa 1948).

66 See United Artists Corp. v. Strand Prods., Inc., 216 F.2d 305 (9th Cir. 1954).

67 In re Progress Lektro Shave Corp., 35 F. Supp. 915 (D. Conn. 1940).

68 Assignments of copyrights are void as against bona fide purchasers or subsequent lienholders unless recorded in the Copyright Office within three months of the assignment or six months for assignments made outside the United States. 17 U.S.C. $\$ 30$ (1958). Similar provisions apply to patents, 35 U.S.C. \$ 261 (1958), and to trademarks, 60 Stat. 431,15 U.S.C. $\$ 1060$ (1958). 
Waterson indicates that the power of rejection may not be used in this way: The equitable lien of the composer prevails over the rights of the trustee. And even if the trustee can show that the assignor's interest is the kind of property upon which a creditor of the bankrupt "could have obtained a lien by legal or equitable proceedings at the date of bankruptcy ...," the Waterson line of cases seem to imply that section 70c should not be applicable. ${ }^{69}$ This special treatment accorded creative forms of property may result from the judicially created policy of protection and encouragement of creative genius. Just as creative efforts are encouraged by granting a monopoly for years under the patent and copyright laws, so business transactions entered into by creative persons for the promotion of their creations are entitled to greater security than are ordinary transactions when bankruptcy supervenes.

(10) The bankrupt is the vendor of chattels that are being specially manufactured for the vendee ${ }^{70}$ or that are otherwise unique. ${ }^{71}$ The proper test for rejection here is whether the performance of the contract would harm other creditors of the bankrupt. ${ }^{72}$ If performance would merely substitute cash for chattels in the estate, the contract should be non-rejectable. On the same principle, the vendee is entitled to specific performance. If the performance of the contract would, however, reduce the general estate available to creditors, rejection is proper. In cases of unusual hardship on the vendee, it might be proper for the court to deny rejection on condition that the vendee agree to a higher purchase price. This kind of order would operate on the same principle as readjustment of an executory lease as proposed in section III. It is useful to compare the treatment of an executory contract for sale of unique chattels with an executory contract for sale of real estate. ${ }^{73}$ The two situations should be handled consistently.

(11) In reorganizations involving public utilities, the court may refuse rejection because of a countervailing public policy.74 For example, the

69 At the time of the Waterson decision, the comparable provision was found in \& 47a(2), which had been enacted in 1910 .

70 Hurley v. Atchison, T. \& S.F. Ry., 213 U.S. 126 (1909).

71 See the cases collected in 5 CorBIN, ConTracts $\$ \$ 1146,1156$ (1951); ChAFEE \& RE, Equrry 171-207 (4th ed. 1958).

72 See the illuminating discussion in Horack, Insolvency and Specific Performance, 31 HARV. L. REv. 702 (1918).

73 See text accompanying notes $45-47$ supra.

74 In Birmingham Trust \& Sav. Co. v. Atlanta, B. \& A. Ry., 271 Fed. 731 (N.D. Ga. 1921), the court held it improper for a railroad receiver to reduce wages payable under employment contracts, since to do so would violate a requirement of notice and hearing prescribed in the Newlands Act. In Ottenheimer v. Whitaker, 198 F.2d 289 (4th Cir. 1952), the court refused to allow the trustee to abandon three worthless 
trustee of a railroad in reorganization may not reject a contract with another line for use of a track or trestle without obtaining the permission of the Interstate Commerce Commission to abandon the service involved. ${ }^{75}$ And in a chapter $X$ reorganization, the trustee may not reject a contract in the public authority, such as a contract between a transit company in reorganization and a city, whereby the company is to operate transit lines owned by the city. ${ }^{78}$

Thus, rejection will be allowed only if the contract is executory as to at least one party, usually the bankrupt or debtor in reorganization, and only if performance would be burdensome or unprofitable to the estate. Nevertheless, the power of rejection cannot be used to destroy an otherwise valid security interest, the estate of a lessee, the equitable interest of the owner of creative property, or, in some instances, the equity of the vendee of real estate or unique chattels. Nor may the trustee reject a public utility contract if to do so would contravene an important public policy.

The foregoing statement of the principle of rejection tends to obviate the problem of deciding when the contract is no longer executory, 77 and avoids the rigid rule that the contract must be executory as to the bankrupt or debtor.78

barges that would probably have sunk in Baltimore harbor, thus obstructing navigation. See 13 MD. L. REv. 229 (1953).

75 Thompson v. Texas Mex. Ry., 328 U.S. 134 (1946); Gaston v. Rutland R.R., 35 F.2d 685 (2d Cir. 1929), cert. denied, 281 U.S. 728 (1930); cf. Smith v. Hoboken R.R., Warehouse \&: S.S. Co., 328 U.S. 123 (1946).

76 This provision was in old $\S 77 \mathrm{~B}(\mathrm{c})(6)$ but was omitted in the Chandler Act, H.R. 8046, 75th Cong., 1st Sess. (1937), as passed by the House, apparently because it was thought to be covered by other provisions in the act or by general principles of case law. The Senate inserted the public authority exception, apparently upon the basis of a letter from Mayor LaGuardia and of statements by Rep. Celler and others. Hearings on H.R. 8046 Before a Subcommittee of the Senate Committee on the Judiciary, 75th Cong., 2d Sess. 171-99 (1938) (especially statement of Weinstein at 197). See also S. REP. No. 1916, 75th Cong., 3d Sess. 6 (1938); Gerdes, Section 77B, The Chandler Bill and Other Proposed Revisions, 35 Mrcr. L. Rev. 361, 397 (1937). But a trustee of a municipal transit company may reject the lease of a branch line despite the lessor's argument that it is a contract in the public authority. In re Chicago Rapid Transit Co., 129 F.2d (7th Cir.), cert. denied sub nom. Chicago Junction R.R. v. Sprague, 317 U.S. 683 (1942).

77 See In re H.K. Porter Co., 24 F. Supp. 766 (W.D. Pa. 1938) (see note 40 supra). Must the contract be executory as to both the bankrupt and the creditor? Suppose a third party holding a security interest is involved, as in In re Italian Cook Oil Corp., 190 F.2d 994 (3d Cir. 1951) (see note 40 supra). Must the contract be executory as to all three parties? If the debtor has made an assignment of future rents or other accounts receivable, has he completed his performance? Questions such as these baffle analysis in terms of when the contract is executory.

78 In re Pagliaro, 99 F. Supp. 548 (N.D. Cal. 1951), aff'd sub nom. Costello v. Golden, 196 F.2d 1017 (9th Cir. 1952); In re San Francisco Bay Exposition, 50 F. Supp. 344 (N.D. Cal. 1943). 


\section{LESSOR IN BANKRUPTCY OR REORGANIZATION}

Under the principle of rejection is a lease different from other kinds of executory contracts? Rejection first appeared in cases of bankrupt lessees; the first reported case involving a bankrupt lessor came much later. Although a leasehold has, for historical reasons, been regarded as personal rather than real property, ${ }^{79}$ historical distinctions make little sense in the modern commercial world where the lease often does the work of the contract or where a lease and a contract are used together for a single business arrangement. ${ }^{50}$ Moreover, the modern lease plays many roles: The nonrenewable long-term lease resembles a mortgage; the renewable long-term lease is tantamount to a grant of the fee; the medium-term lease with option to purchase is like a purchase contract; the shopping-center lease is used to control the development and use of land, much like restrictive covenants in grants of the fee; still other purposes are served by the sale and lease back, the leased department in a retail store and the proprietary leasehold.81 Where the modern lease is like a transaction in personalty, it ought to be subject to the same risks. In some situations, however, it is socially desirable that the lessee have a high degree of assurance that his possession will not be interrupted by lessor bankruptcy. The lessee with a large investment in equipment, inventory and good will, for instance, has a legitimate claim to greater protection than the ordinary unsecured creditor. But the law on this point remains uncertain.

Section 70b of the Chandler Act of 1938, as amended in 1962, includes the following provision:

Unless a lease of real property expressly otherwise provides, a rejection of the lease or of any covenant therein by the trustee of the lessor does not deprive the lessee of his estate. ${ }^{82}$

This may be called the lessor provision and its purpose is to limit the trustee's power of rejection. But is it declaratory of pre-existing law or does it afford to lessees some new protection not previously available? What, precisely, is the content of the lessee's "estate"?-Is it the sum of the rights arising from the lessor's covenants in the lease, or merely

79 I Gasner, American Law of Property 175-78 (1952).

80 Id. at 202-05. See generally CLARK, REAL Covenants AND Other INTERests Which "Run WITH LAND" ch. 4 (2d ed. 1947).

81 Today the sale and use of land and the financing thereof resemble other commercial transactions more and more. Bookstaver, Book Review, 12 J. LEG. ED. 150 (1959).

82 As originally adopted in 1938, the provision was the same except that the future tense was used: "Unless a lease of real property shall expressly otherwise provide, a rejection of such lease or of any covenant therein by the trustee of the lessor shall not deprive the lessee of his estate." 52 Stat. 840 (1938). 
the right of possession at a fair rental to the end of the term? If the lease is unrecorded but the lessee is in possession, is his estate protected against the trustee? To what extent, if at all, does the lessor provision apply under chapters X to XIII of the Bankruptcy Act?

In applying the lessor provision in straight bankruptcy, the court reconciles the conflicting interests of the unsecured creditors and of the lessee. Such creditors want the maximum assets available for distribution to them; the lessee wants to continue in possession under his original lease. The unsecured creditors will want the trustee to reject the lease, if the premises can be sold for a better price free and clear of the lease, as, for instance, when the prospective purchaser of the freehold is prepared to occupy the premises himself or lease them at a higher rental. But the lessor provision stands in the way, guaranteeing that a rejection "does not deprive the lessee of his estate." Clearly, the policy of this provision is to favor the lessee over the unsecured creditors. Yet the careful lawyer still fears that in some circumstances a court of bankruptcy would allow rejection at least in part, such as rejection of those of the lessor's covenants that do not run with the land. This is the heart of the problem of the lessor provision.

Did the lessor provision grant to the lessee rights not accorded by the preexistent case law? Most of the cases before the Chandler Act involved receivership rather than bankruptcy, but the principle is the same. In Coy v. Title Guar. \& Trust Co. ${ }^{83}$ the receiver of the lessor was permitted to reject an executory lease for a barber shop and public bath in an office building, since the lease was burdensome to the estate and would reduce the sale value of the building. In American Brake Shoe Co. $v$. New York Rys., ${ }^{84}$ the receiver applied for permission to reject a lease of an office building, contending that it would be burdensome to perform covenants requiring the lessor to furnish heat, electricity, etc. The court declared that ordinarily a court of equity should not allow disaffirmance

merely because the corporate lessor made what, at this moment, might be a bad bargain, although a good enough bargain originally. It is the duty of the receiver to make every proper effort to increase the assets of an estate, but not at the expense of fundamental principles of fair dealing. When a lessee under a lease takes possession, the lease presupposes continuance, even in the face of a receivership of the landlord, so long as the landlord's receivership estate is not burdened or put to loss, and by "burdened" is not meant that the lease could be more profit-

83198 Fed. 275 (D. Ore. 1912).

84278 Fed. 842 (S.D.N.Y. 1922). 
able, but that it entails a positive loss or encroachment on the corpus or capital of the estate. 85

The court went on to say, however, that the trustee could later apply for rejection if performance should become burdensome. Although this court upheld the lessee's rights, it indicated that it would allow outright rejection if conditions should change. Thus the court seems to contemplate only two possibilities-either complete enforcement or complete rejection. Is there a middle road? Why not permit the lessee to remain in possession on condition that he pay higher rent or assume the cost of the utilities?86

Additional support for the lessee appears in an early New Jersey decision. ${ }^{87}$ The court allowed a preferred claim for damages against a receiver who had rejected an agreement to rent space for a soda fountain in an office building. The court said that the receiver took possession of the lessor's estate "cum onere, subject to the contract of letting entered into by the [lessor]." The opinion indicates that the court would likewise have granted specific performance to the lessee. Commentators have also advocated preserving the leasehold against the trustee. ${ }^{88}$ It seems clear, however, that prior to the Chandler Act, the few cases were so conflicting that in most jurisdictions the lessee had little if any assurance that he would be protected upon bankruptcy or receivership of the lessor. In a variety of situations short of straight bankruptcy, the lessee did find himself without assurances of protection of his leasehold. For example, where the assets were insufficient to pay any creditor ranking below the first mortgagee, the court approved a plan of reorganization under former section 77B that required rejection of a lease subordinate to the mortgage. The court ruled that "the lien of the lease arises to no greater dignity than a second mortgage on the premises." 89 It is the prevailing American view that a purchaser of real property at a mortgage foreclosure sale can reject a lease subordinate to the mortgage if the lessee was a party in the foreclosure suit. ${ }^{90}$ And a lessor who rightfully termi-

$85 \mathrm{Id}$. at 843 .

86 See the text in the paragraph following note 109 infra.

87 Bolles v. Cresent Drug \& Chem. Co., 53 N.J. Eq. 614, 32 Atl. 1061 (1895); cf. In re Hays, Foster \& Ward Co., 117 Fed. 879, 884 (W.D. Ky. 1902) (dictum about rights of lessee against purchaser of freehold).

88 Finletter, Bankruptcy Reorganization 240 (1939); Payne, The General Administration of Equity Receiverships of Corporations, 31 YALE L.J. 685 (1922).

89 In re Hotel Governor Clinton, Inc., 96 F.2d 50, 52 (2d Cir. 1938); cf. In re Banner, 149 Fed. 936 (S.D.N.Y. 1907). For comment justifying the Governor Clinton decision, see Note, 48 YAlE L.J. 1415, 1420 (1939).

90 Tiffany, Real Property § 153 (3d ed. 1939); Annot., 14 A.L.R. 664 (1921). In some states, such as Pennsylvania, the same rule applies even if the lessee is not 
nates a lease may likewise revoke a sublease, even though the sublessee is willing to step into the shoes of the lessee and perform all his covenants to the lessor. 01

Professor MacLachlan, in 1927, recognized the insecurity of the lessee and proposed that section 70 of the Bankruptcy Act be amended by adding the following sentence:

The bankruptcy of a landlord, however, shall not work a forfeiture of a tenant's estate and shall give the tenant's trustee in bankruptcy no election to terminate the estate. ${ }^{22}$

Later, Professor MacLachlan said that this proposal was the source of the 1938 version of the present lessor provision..$^{33}$ It thus seems an inescapable conclusion that the lessor provision was intended to grant the lessee protection that the existing law either failed to provide clearly or failed to provide at all.

What is the content of the new protection afforded the lessee? What is the lessee's "estate" that the trustee may not take away by rejection?

made a party. Farmers' \& Mechanics' Bank v. Ege, 9 Watts 436 (Pa. 1840). Professor Tefft argues persuasively that a lease ought not be disturbed unless the mortgagee's security cannot be preserved in any other way. Tefft, Receivers and Leases Subordinate to the Mortgage, 2 U. CHI. L. REv. 33, 35-36 (1934). This is the rule in England, but is only a minority rule in the United States.

21 Brock v. Desmond \& Co., 154 Ala. 634, 45 So. 665 (1908); Bush v. Bourland, 206 Ark. 275, 174 S.W.2d 936 (1943); Herman v. Campbell, 86 Cal. App. 2d 762, 195 P.2d 801 (1948); Hawley Corp. v. West Va. Broadcasting Corp., 120 W. Va. 184, 197 S.E. 628 (1938). Cf. Cohen v. Sylvan Lawrence Co., 166 A.2d 919 (Munic. Ct. App. D.C. 1961) (sublessee could not recover security deposit from successor of sublessor, who had defaulted on head lease); Kerr v. Capital Grocery, Ltd., [1951] I West Weekly R. (Sask.) 1221, 59 D.L.R. 388 (1920) (assignment for benefit of creditors). But see Shaw v. Creedon, 183 N.J. Eq. 397, 32 A.2d 721 (1943). The traditional concept is that a sublease falls with the head lease, like the branch of a tree that is cut down. Since under the American Bankruptcy Act the courts apply the state law of landlord and tenant, the usual result upon the bankruptcy of the head lessee is that either the head lessor or the trustee may reject the sublease. In the English Bankruptcy Act this old rule has been modified so as to permit the underlessee (as he is called in England) or the mortgagee of the leasehold to obtain an order vesting the lessee's estate in himself if he will assume the lessee's obligations to the lessor, or in the alternative if the underlessee or mortgagee will assume the obligations of an assignee of the interest of the head lessee. Bankruptcy Act, 1914, 4 \& 5 Geo. 5, c. 59, § 54(6); see notes 45-47 supra and accompanying text.

92 McLaughlin, Amendment of the Bankruptcy Act, 40 Harv. L. Rev. 583, 605-06. He said at 609: "The lease will not ordinarily involve heavy burdens on the landlord such as that of making extensive repairs. If it does, the trustee of the landlord ought to be able to repudiate such obligations and the bankrupt landlord ought to be free of them and the tenant remitted to proof of claim in bankruptcy. However, it would be going unreasonably far to provide that the bankruptcy of a landlord forfeits the tenant's estate unless the trustees and the tenant agree to carry on ...."

83 Interview with Prof. MacLachlan March 10, 1958. He also stated that he had taken the idea from the English Bankruptcy Act. 
The content of the lessee's estate is usually a matter of state law. This is because a court of bankruptcy applies the property law of the state where the leased premises are located. This rule is dictated by a widely accepted principle of conflict of laws rather than a specific provision of the Bankruptcy Act or other federal statute. ${ }^{94}$ In applying state law, the federal court of bankruptcy must choose between two possible meanings of the lessee's "estate"; one meaning is broad, the other narrow.

Under the broad meaning, the content of the lessee's "estate" is clear. According to the Bankruptcy Act, the trustee is "vested by operation of law with the title of the bankrupt ...."95 When this provision is read in pari materia with the lessor provision, the former seems to say that the trustee succeeds to precisely the same benefits and burdens under the lease as the lessor himself had before bankruptcy. The transfer is like a devolution to the lessor's heirs upon his death. This is not an ordinary commercial assignment. The lessee is entitled to have the trustee perform every covenant in his lease except, of course, a personal covenant that only the lessor himself could perform-for instance, a covenant not to compete in the same locality. If the lessor's trustee is forbidden to reject any covenant in the lease, he must sell the freehold subject to the lease; and according to general principles of property law, the purchaser must recognize the real covenants of the lease as being in full force and effect. ${ }^{96}$ In re New York Investors Mut. Group, Inc., ${ }^{97}$ the sole reported case that applies section $70 \mathrm{~b}$ to a lessor bankruptcy, seems to support the broad understanding of "estate." The bankrupt lessor owned a valuable corner in Manhattan. In 1914, the property was leased for twenty-one years. In 1935, the original lease was renewed for twentyone years. In 1953, the lessee assigned its interest to East Netherland Holding Company. The 1914 lease and the 1953 assignment were recorded, but the 1935 renewal was not recorded at the time the lessor was thrown into involuntary bankruptcy in 1955. The 1935 renewal provided that at the end of the term, the lessor must either renew the lease or purchase the lessee's improvements of the premises. Three buildings had been erected at the time of bankruptcy. The trustee filed a motion asking leave to sell the property free and clear of the lease and to limit the lessee to the standing of an unsecured creditor as to the value of the buildings; this motion was in effect a motion to reject the lease, or at least to reject the covenant requiring renewal or purchase. The

94 GoODRICH, Conflict of LAws \& 148 (3d ed. 1949). This rule was not affected by the decision in Erie R.R. v. Tompkins, 304 U.S. 64 (1938).

95 Bankruptcy Act $\S 70$ (a), 30 Stat. 565 (1898), as amended, 11 U.S.C. $\$ 110$ (a) (1958).

9832 AM. JUR. Landlord \& Tenant § 97, at 106 (1941).

97153 F. Supp. 772 (S.D.N.Y. 1957). 
trustee asserted that the word "estate" in the lessor provision of section $70 \mathrm{~b}$ meant only the right to remain in possession for the unexpired term of the lease-seven months. The court overruled this contention, saying:

The right of the tenant "not to be compelled to surrender the premises until such payment [for the value of the buildings] be made or tendered" was part of the "estate" granted to the tenant and was a covenant which was not destroyed by the trustee's notice of rejection.

A tenant's right to possession of land constitutes part of the "estate" granted to him. [Citing a New York decision.] The strict interpretation of "estate," as urged by the trustee, so as to make it co-terminous with the 21-year period notwithstanding that the landlord failed to make payment for the buildings contrary to the covenant in the lease, denudes the lease of the clear purpose intended by the parties and deprives the tenant of the full enjoyment of his estate ....98

On appeal by the trustee and an intervening mortgage creditor, the court of appeals affirmed,98 emphasizing that even though the 1935 renewal was unrecorded, common creditors had constructive notice because the lessee was in possession.

Despite the district court's broad interpretation of the lessor provision, language in the opinion suggests a narrower concept of the lessee's estate. (The court of appeals did not consider this point.) According to this narrow interpretation, the transfer of the lease from the lessor to the trustee should be treated like any other assignment of an estate in land. Therefore, only covenants that run with the land are binding upon the trustee or his vendee. Supporting this interpretation is the following passage, which appears shortly after the passage quoted above:

The New York law on the subject is clear, First, a covenant by the landlord to pay a tenant the value of the buildings upon the expiration of the lease is a covenant running with the land. Second, where the parties expressly agree a tenant is entitled to possession until actual payment is made, he has a lien until the payment is made. It is only where there is no express or clearly implied provision for a lien to secure the payment for the improvements upon expiration of the lease, that the lessor's liability is only for money damages .... 100

The necessary implication is that if the covenants did not run with

98 Id. at 775 .

99 Cohen v. East Netherland Holding Co., 258 F.2d 14 (2d Cir. 1958).

100 In re New York Investors' Mut. Group, Inc., 153 F. Supp. 775 (S.D.N.Y. 1957) (citations omitted). 
the land, but were merely personal to the lessor, then the lessee could not prevent rejection. The decisions of the several states are in conflict as to which of the lessor's covenants run with the land.101

Although the result in the New York Investors case would have been the same under either concept of the nature of the assignment to the trustee, in other cases the result would depend on which concept the court chose to apply. If the narrow interpretation is used-that the assignment includes only covenants that run with the land-then another problem arises. In the American Brake Shoe case, ${ }^{102}$ the court refused to permit outright rejection of the lease but said the receiver could later apply for permission to discontinue providing utilities if this should become onerous. In the Coy case, ${ }^{103}$ the court allowed the receiver to reject a covenant to renew. Payne, ${ }^{104}$ and later Finletter, ${ }^{105}$ apparently interpreted these cases as drawing a distinction between real and personal covenants: Only the personal covenants are rejectable. But the author submits that Congress intended to change this rule when it enacted the lessor provision in 1938. Another commentator asserts that under section $70 \mathrm{~b}$, the trustee of a lessor would have to leave the lessee in possession but could reject the rent provision of the lease. ${ }^{106}$ This restrictive interpretation would oppress the lessee because the amount of rent is usually one of the chief terms of his bargain.

Could a court of bankruptcy refuse to apply state law, under which an important covenant was personal and hence rejectable, and instead enforce the covenant? In Local Loan Co. $v$. Hunt, ${ }^{107}$ the Supreme Court ruled that the bankruptcy principle of assuring the debtor a discharge was paramount to Illinois law, which recognized an assignment of future wages. As MacLachlan says in commenting on this decision,

The law of property and of contracts will be followed in the ordinary case without even arousing consciousness of any lurk-

101 Clatk, Real Covenants \& Other INTERests Which "Run WTth LAND" 96-100 (2d ed. 1947); 3 Thompson, Real Property 407-11 (Grimes ed. 1959). See also Goodrich, op. cit. supra note 94 , at $\S 150$.

102 Note 84 supra.

103 Note 83 supra.

104 The General Administration of Equity Receiverships of Corporations, 31 YALE L.J. 685, 693-95 (1922). He also suggests that the possession of the tenant must remain intact because this right is no longer executory, but all covenants prescribing executory duties of the lessor may be rejected, such as a covenant to renew.

105 BANKRuptcy Reorganization 240 (1939).

106 Garrett, Lease Provisions Against Special Contingencies, 1952 In.. L. Forum 395, 404. Garrett suggests that the lessee's estate may be separated into an estate in land and the contractual rights, the latter subject to rejection.

107292 U.S. 234 (1934). 
ing questions, but the state law will not be followed with reference to minority doctrines or tortuous concepts which defeat the basic purposes of the national legislation. ${ }^{108}$

To apply a tortuous or minority rule of state law in considering the covenant personal would frustrate the purpose of the lessor provision, just as the Illinois law frustrated an important bankruptcy purpose in the Local Loan case. Of course, a knowledgeable attorney for the lessee can include in the lease a provision that the covenant to renew shall be deemed to run with the land. But rarely does the lessee or his attorney consider the possible bankruptcy of the lessor. Indeed, most leases are drawn by the lessor anyway, and what lessor will contemplate his own bankruptcy and put in a provision to protect the lessee? Admittedly, if the court applies the Local Loan doctrine so as to forestall rejection of onerous covenants that do not run with the land under state law, this will prevent a possible increase in the lessor's estate available for general creditors. But is this an asset that the general creditors should have? No doubt they have extended credit to the bankrupt in reliance, inter alia, upon his ownership of real estate which they might reasonably have assumed was leased upon favorable terms. But should they be able to rely upon the possibility of rejecting an unfavorable covenant? If the lease is of record, the answer is clear. The creditors have constructive notice of the lease. They have no rights in bankruptcy as against the lessee. If the lease is not of record but the lessee is in possession, the creditors may have constructive notice. ${ }^{109}$ If the lease is not of record and the lessee is not in possession, then the policy of protecting the lessee's estate collides with another bankruptcy policy-the policy against secret liens and preferences. Although it might be argued that other provisions of the Bankruptcy Act were enacted to protect general creditors, the lessee here should have no rights as against the common creditors, hence rejection is proper.

Still another aspect of the meaning of the lessee's "estate" remains to be explored. If the narrow interpretation is accepted and the state law of covenants running with the land is not a "minority doctrine or tortuous concept," then the Local Loan rule would not apply. Thus, the trustee could assert a right to reject the bankrupt's personal covenants with the lessee, i.e., those covenants defined by state law as not running with the land. Should the court allow outright rejection of an option to renew the lease? A provision on the amount of rent? An agreement to supply

108 MACLACHLAN, BANKRUPTCY 108 (1956).

109 Cohen v. East Netherland Holding Co., 258 F.2d 14 (2d Cir. 1958). Compare UNIFORM COMMERCLAI CODE $\$ \S$ 9-402, 9-302, 9-303 (financing statement without details as to specific chattels is constructive notice). 
utilities? Would not rejection of such covenants take from the lessee vital portions of his contract if not his estate? The lessee wants performance of the personal covenants as well as the real. But the common creditors want the trustee to reject all personal covenants if the lessor's estate is more valuable without them. Perhaps the best solution is a middle way, taking account of the competing equities of both sides. Suppose the lessor is a corporation that owns a shopping center and the lessee operates a men's clothing store there. The premises are a storeroom renting at 500 dollars a month with two years remaining under the lease at the time of bankruptcy. The lessee has an option to renew for five years at 600 dollars a month. The lessor has also covenanted to provide heat, light, water, air conditioning and trash disposal, and to repair the outside of the building. Another covenant binds the lessor not to lease to another men's clothing store elsewhere in the shopping center. Suppose further that none of these covenants run with the land under applicable state law and that the court has decided that the Local Loan doctrine does not apply. If the sales volume of the shopping center is rapidly increasing, the trustee wants to reject all the covenants so that the center can be sold free and clear of the obligation of the lease. In this example, the fairest solution would be a middle road between complete performance of the personal covenants and complete rejection. Perhaps a satisfactory new lease could be negotiated by the trustee and the lessee. Failing this, the court might decree that the trustee or his assignee perform all covenants of the lease on condition that the lessee pay a larger rent sufficient to cover increased costs of operation by the lessor. This solution-a rewriting of the rent covenant-may be compared with the flexible rent provisions included in some modern leases. ${ }^{110}$

Does a court of bankruptcy have the power to allow the trustee to rewrite the rent provision of the lease without a specific statutory authorization? The court does have such power, for two reasons: (I) If the court may allow the trustee to reject all of the personal covenants of the lease, a fortiori the court may allow him to reject only one or two of them; (2) This power is similar to or included in the broad powers provided in chapters $X$ to XIII for scaling down of creditors' rights, which in turn derive from the broad powers exercised by the federal courts in equity receiverships before enactment of the amendments of the 1930's.111 This middle-road formula has the advantage of preserving what are usually the most important provisions of the lessee's bargain,

110 See Denz, Lease Conditions Designed to Meet Changing Economic Conditions, 1952 ILL. L. FORUM 344, for a compilation of the various possible provisions.

111 See Finletter, Corporate Reorganization (1937); Payne, The General Administration of Equity Receiverships of Corporations, 31 YALE L.J. 685 (1922). 
while at the same time recovering for the general creditors at least that part of the enhancement in rental value resulting from higher costs for insurance, utilities, taxes and maintenance, rather than any improvements made by the lessor. The lessee would still have the benefit of any increase in rental value because of such factors as inflation and population growth.

If a mortgage ranks ahead of the lease, the foregoing analysis would still apply. Where the property is worth more than the mortgage, according to the official appraisal in bankruptcy, the trustee can either sell the property subject to the mortgage or sell free and clear of the mortgage, using the proceeds to pay off the mortgagee. In neither event could the mortgagee reject the lease, since he would be paid in full.112 The trustee or his assignee would have no more right to reject the lease than he would have absent the mortgage.

If the property is worth less than the mortgage, the trustee may either abandon the property to the mortgagee or sell it and pay the proceeds to the mortgagee, leaving him to file a claim as a common creditor for the balance due. If the property is abandoned to the mortgagee and he forecloses and sells the property, the purchaser could in most states reject the lease, especially if the lessee were made a party to the foreclosure suit. This would apply even if the mortgagee himself bought at the sale. If the trustee sells the property instead of abandoning it, the vendee would have the same rights as a vendee at a foreclosure sale. Thus, where the lease is subordinate to the mortgage and the mortgage is of greater value than the freehold, the lessee faces the expensive prospect of either losing his lease, purchasing the reversion or purchasing the mortgage. What can the lawyer for the lessee do to prevent this when the lease is first drafted? (I) He can insert a provision that all covenants shall be deemed to run with the land. (2) He can ask for a provision that in event of insolvency of the landlord, including bankruptcy, the lessee shall have an option to purchase the reversion, the price either being stated or made readily ascertainable. It may also be possible for the lessee's attorney to get the mortgagee to agree that the mortgage is subordinate to the lease.

To sum up, the broad interpretation of the lessor provision of section $70 \mathrm{~b}$ is the correct one. None of the lessor's covenants may be rejected, whether real or personal. Nevertheless, if the narrow interpretation is accepted-that the personal covenants may be rejected-then the rule is subject to two limitations. (1) Where the applicable state law is an unusual law out of keeping with the policy of the lessor provision, the 
state law need not be followed. (2) A readjustment of the rent term of the lease or other comparable terms is preferable to outright rejection. It should make no difference if there is a mortgage superior to the lease.

It remains to consider the application of the lessor provision in reorganizations and arrangements under chapters $X$ to XIII. In a reorganization or arrangement, the objectives are similar but not identical to those in straight bankruptcy. The debtor usually has some voice in the management of the estate in a reorganization or arrangement, but he has none in bankruptcy. Although all of the different proceedings under the Bankruptcy Act are intended to benefit creditors as much as possible, the theory of a reorganization or arrangement is that the creditors, by making a sacrifice now, will recover more later. But in straight bankruptcy, the creditors expect prompt liquidation and distribution. Just how do these somewhat different objectives in reorganization and arrangement proceedings affect the application of the lessor provision? Should the tenant's leasehold have less protection when the landlord's estate is being rehabilitated than when it is being liquidated?

The legislative history offers no guidance. The Chandler Act, which first added chapters X to XIII to the Bankruptcy Act, ${ }^{113}$ did not include any lessor provision. Each of these chapters, however, contains a provision incorporating the provisions of chapters I to VII "insofar as they are not inconsistent or in conflict with the provisions of this chapter ...."114 Although the reports of the congressional committees do comment on section $70 \mathrm{~b}$ and related sections in other chapters, ${ }^{115}$ these reports do not touch the lessor provision.

In proceedings under chapters $\mathrm{X}$ to $\mathrm{XIII}$, the common creditors always, and often secured creditors, are asked to accept an extension of time for payment, a reduction of amount, a diminution of security or a combination of these. The incorporation in chapters X to XIII of the provisions of chapters I to VII in effect constitutes a presumption that the usual bankruptcy provisions shall operate unless inconsistent with the purposes of the later chapters. ${ }^{116}$ Is it inconsistent with the provisions of chapters

113 The Bankruptcy Act formerly contained much less elaborate provisions for compositions. See Bankruptcy Act $\S 12,30$ Stat. 549 (1898), $\S 74$ added by Act of 1933, 47 Stat. 1467, as amended, 11 U.S.C. $\$ \S 30,202$ (1934).

11452 Stat. 883, 905, 916, 930 (1898), 11 U.S.C. $\$ \S 502,702,802,1002$ (1958).

115 H.R. REP. No. 1409, 75th Cong., Ist Sess. 34 (1937); S. REP. No. 1916, 75th Cong., 3d Sess. 18 (1938). See also House Comm. on Judiciary, 74th Cong., 2D SEss., ANALYSIS OF H.R. 12889, 227 (Comm. Print 1936).

116 Bankruptcy Act $\S \S 236,376,481,666,52$ Stat. 899, 912, 924, 936 (1938), II U.S.C. $\$ \S 636,776,881,1066$ (1958). Although one might not ordinarily think of a wage earner as a landlord, chapter XIII does allow rejection of executory contracts, including unexpired leases. 52 Stat. 930, 933, 934 (1938), I1 U.S.C. $\S \S 1006(5), 1042,1046(6)$ (1958). 
$\mathrm{X}$ to XIII to assure the lessee as great security in his leasehold in reorganization as he enjoys in straight bankruptcy? In a commercial bankruptcy the creditors are usually businessmen who are accustomed to assuming the risk of bad accounts as part of their cost of operation. In the noncommercial bankruptcy, the creditors are typically retailers, finance companies, hospitals or doctors, most of whom can protect themselves through, for instance, credit reports, co-signers or chattel security. The lessee of the bankrupt stands in a different position: He has not furnished the bankrupt with goods or services on credit. Although theoretically the lessee can protect himself against the lessor's insolvency, he usually is not protected, especially if the lessor draws the lease. What has been said about commercial bankruptcy applies to proceedings under chapters $\mathrm{X}$ to XII, and the comment about non-commercial bankruptcy applies to chapter XIII. It is inappropriate and unfair to subject the lessee to any more alteration of his lease under chapters $X$ to XIII than in straight bankruptcy. One concludes that vis-à-vis common creditors and those holding chattel security, the lessee's estate should be preserved the same as in straight bankruptcy. The lessor provision of section $70 \mathrm{~b}$ should be read into chapters X to XIII to this extent.

But what about the standing of a lessee vis-à-vis the holder of a mortgage on the freehold? If the mortgage is subordinate to the lease, the conclusion just stated should apply. But if the mortgage is superior to the lease and if the plan of arrangement requires the mortgage creditor to accept an extension, reduction or diminution of security, to accord the lessee the same rights as in straight bankruptcy would be to prefer him over the mortgagee. Any impairment of the rights of the mortgagee enhances the value of the subordinate leasehold. It follows that if the mortgagee should foreclose and sell the freehold, the purchaser could reject the lease. Therefore, in a proceeding under chapters $\mathrm{X}$ to XIII, a plan that reduces the rights of the mortgagee may properly require a commensurate alteration of the lease. For example, if the mortgagee agrees to a lower rate of interest and a longer period of repayment, the lessee could properly be required to pay more rent or assume the responsibility to pay for utilities. In altering the terms of the lease, the court should take into account such factors as the time remaining under the lease, the cost of removal to another location, good will, investment in fixtures and conformity by the lessee to building, zoning and health regulations. If the plan of reorganization or arrangement does not require the superior mortgagee to alter his rights, and if the freehold is worth more than the mortgage, then the lessee ought not be required to accept any alteration. In reorganization, as in straight bankruptcy, if the amount of the mortgage equals or exceeds the appraised value of the 
freehold and if the trustee retains the property rather than abandoning it to the mortgagee, then the lien of the subordinate lease has little or no value. Here, it would be proper to require the lessee to accept some alteration of the lease. Thus, in chapters X to XIII, the leasehold should ordinarily be preserved the same as in straight bankruptcy with two exceptions-(1) where a prior mortgage is altered, and (2) where a prior mortgage is left intact but the lessor's estate has no equity in the freehold.

Only In re Freeman, 117 a chapter XII proceeding filed by a husband and wife individually and as partners in a business, has specifically considered whether the lessor provision of section $70 \mathrm{~b}$ applies to chapters X to XIII. The trustee sought to reject a lease, subordinate to a mortgage, on a residence owned by the husband that had less than a year to run. The trustee showed that on foreclosure and sale the property would not yield any surplus for the husband's estate. A purchaser offered to pay. 750 dollars for the property and to assume the mortgage if the burden of the lease could be lifted. The tenant had been given an opportunity to purchase the property but had not done so. He objected to the rejection, arguing that the lessor provision of section $70 \mathrm{~b}$ applied in chapter XII. The court allowed the trustee to reject the lease on two grounds: (1) The lessor provision did not apply because it is inconsistent with the purposes of chapter XII;118 (2) The tenant had no special equities in his favor. The court thought recovery of 750 dollars for the husband's estate was more important than preservation of the leasehold, since the 750 dollars swelled the assets of the estate and presumably helped persuade the creditors to accept the plan of arrangement. The result seems correct when one considers that the leasehold had no value, if treated as a lien subordinate to the mortgage. Yet, if the leasehold had no value, where did the 750 dollars differential come from? This figure can be at least partly explained as court costs, legal fees, and the general shrinkage in value that usually accompanies a forced sale. Also it was hard to find housing in 1943 because of the war, so a buyer might well pay a premium for immediate possession as distinguished from possession at the end of the lease or after a foreclosure proceeding. Furthermore, property often has two prices-one for all cash and a higher price if the

11749 F. Supp. 163 (S.D. Ga. 1943).

118 "To give to the word 'estate' as used in § 110, sub b [the U.S.C. number for $\S 70 \mathrm{~b}]$ of Chapter VII the meaning petitioner suggests, viz., a right to continue to occupy the premises until the end of the term, renders the section authorizing rejection of executory contracts impotent to accomplish the ends for which it was designed. To give it that meaning creates inconsistency and conflict with the purposes of the Arrangement provisions, and where that happens Chapters I to VII are expressly made inapplicable ...."Id. at 165 . 
buyer assumes (or obtains) a mortgage. ${ }^{119}$ Similarly, a property may have a different value with and without a lease even though the lease is profitable, since it restricts the purchaser from using the property himself. It is this difference in value that may properly be claimed for creditors in chapters X to XIII where, because of a prior encumbrance, the leasehold has no value.

The second reason suggested in Freeman-that the tenant had no special equities in his favor such as a commercial tenant might have had -indicates that the court might have denied rejection if the tenant had had such equities as loss of good will, loss of investment in fixtures and expense of removal. It was proper for the court to employ this technique of weighing the equities of the tenant and of the common creditors where the lien of the leasehold had little or no value. This corresponds to the provision of the British Bankruptcy Act permitting the court to impose such conditions as it thinks just upon the granting of leave to disclaim a lease. ${ }^{120}$

The Freeman decision was correct, but it does not stand for the broad proposition that the lessor provision is limited to straight bankruptcy. All that Freeman holds is that where (1) the lease is subordinate to the mortgage, (2) the leasehold has little or no value and (3) the tenant presents no special equities, rejection is proper. Thus limited, Freeman is good law. It would be persuasive in proceedings under chapters X, XI, and XIII as well as XII.

In corporate reorganizations under chapter $\mathrm{X}$, one special rule applies. If the debtor leases property to a municipal transit authority or other public agency, rejection is not permitted regardless of how desirable it might be.121

\section{Lessee IN BANRRUPTCY OR REORGanization}

When a lessee under an unexpired lease becomes bankrupt, his trustee can reject the lease without any limitation such as that obtaining in lessor bankruptcy. ${ }^{122}$ No statutory provision guarantees the lessor his estate. But there are other limitations on the trustee. He must reject or affirm within the time period prescribed in section $70 \mathrm{~b}$, otherwise the lease is deemed to be rejected. Uncertainties did develop as to the time

119 See Riley v. District of Columbia Redev. Land Agency, 246 F.2d 641 (D.C. Cir. 1957).

120 Bankruptcy Act, 1914, $4 \& 5$ Geo. 5, c. 59, § 54(3).

121 Bankruptcy Act $\S 116(1), 52$ Stat. 885 (1938), 11 U.S.C. $\S 516$ (1958). See note 76 supra.

122 See 4 Collier, Bankruptcy 70.44 (14th ed. 1942, 1959 Supp.); Roeder, Landlords, Bankruptcy and 77B, 23 CORNELL L.Q. 285 (1938); Stanley, Leasehold Rights in Bankruptcy and Equity Proceedings, 29 Ky. L.J. 301 (1941). 
period under the 1938 Act, but these have been corrected by the 1962 amendment sponsored by. the National Bankruptcy Conference.123 Section $70 \mathrm{~b}$ also requires the trustee to file a statement with the court showing which contracts and leases are executory and which he intends to reject. If he fails to do this, he may cause a loss to the estate, because of automatic rejection of favorable contracts. ${ }^{124}$

It is not clear to what extent section $70 \mathrm{~b}$ applies in reorganizations and arrangements under chapters X to XIII so far as the lessor is concerned. Often a lessor requires a provision that bankruptcy of the lessee shall automatically terminate the lease. ${ }^{125}$ This kind of provision has usually

123 As amended, the first four sentences of $\S 70 \mathrm{~b}$ provide as follows: "The trustee shall assume or reject an executory contract, including an unexpired lease of real property, within sixty days after the adjudication or within thirty days after the qualification of the trustee, whichever is later, but the court may for cause shown extend or reduce the time. Any such contract or lease not assumed or rejected within that time shall be deemed to be rejected. If a trustee is not appointed, any such contract or lease shall be deemed to be rejected within thirty days after the date of the order directing that a trustee be not appointed. A trustee shall file, within sixty days after adjudication or within thirty day's after he has qualified, whichever is later, unless the court for cause shown extends or reduces the time, a statement under oath showing which, if any, of the contracts of the bankrupt are executory in whole or in part, including unexpired leases of real property, and which, if any, have been rejected by the trustee." Il U.S.C. § 110(b) (Supp. IV, 1963) (Emphasis added to indicate 1962 additions.) By way of explanation of the amendment to $\S 70 \mathrm{~b}, \mathrm{~S}$. RER. No. 1954, 87th Cong., 2d Sess. (1962), said: "This language [prior to amendment] does not give due regard to the contingency that in many instances the trustee may not have been appointed within 6 days after the adjudication or, alternatively, that his appointment may be so close to the expiration of the 60-day period that he has inadequate time to come to a considered decision concerning the assumption or rejection of executory contracts. Moreover, the present language fails to give the due regard to the fact that there may be cases in which no trustee is appointed. The new language in section $70 \mathrm{~b}$ covers this contingency as well." For problems under the former act, see Rickles, Claims Arising From Breach of Executory Contracts, 26 REF. J. 21 (1952).

124 In re Gravure Paper \& Board Corp., 234 F.2d 928 (3d Cir. 1956) (sale of lease at public auction more than sixty days after adjudication did not prevent automatic termination); In re Northern Ind. Oil Co., 180 F.2d 669 (7th Cir. 1950); United States v. Chichester, 312 F.2d 275 (9th Cir. 1963); In re Forgee Metal Prods., Inc., 229 F.2d 799 (3d Cir. 1956) (conditional sale contract); cf. In re Pagliaro, 99 F. Supp. 548 (N.D. Cal. 1951) aff'd sub nom. Costello v. Golden, 196 F.2d 1017 (9th Cir. 1952) (conditional sale contract in which bankrupt had valuable equity); In re Public Ledger, Inc., $63 \mathrm{~F}$. Supp. 1008 (E.D. Pa. 1945) (labor contract). The American statute makes no provision for property unknown to the trustee, but the English statute provides that the time period runs from the time of discovery. Bankruptcy Act, 1914, 4 \& 5 Geo. 5, c. 59, $\S 354(1)$.

125 The sixth sentence of $\S 70 \mathrm{~b}, 52$ Stat. 880 (1938), as amended, II U.S.C. $\S 110(\mathrm{~b})$ (Supp. IV, 1963), provides as follows: "A general covenant or condition in a lease that it shall not be assigned shall not be construed to prevent the trustee from assuming the same at his election and subsequently assigning the same; but an express covenant that an assignment by operation of law or the bankruptcy of a specified party thereto or of either party shall terminate the lease or give the other party an election to terminate the same is enforceable." 
been held to apply to reorganizations and arrangements as well as straight bankruptcy, ${ }^{126}$ but it would be better if the statute said so explicitly since the question is still open in most jurisdictions. Another problem is whether the time limits on the trustee apply to the other chapters. Nothing in the legislative history of either the 1938 Act or the 1962 amendment sheds any light on this question. ${ }^{127}$ Moreover, the court decisions are in conflict on the question. But the better considered decisions hold that the time limitations of section $70 \mathrm{~b}$ do not apply to chapter $\mathrm{X}$ since the objective is rehabilitation of the debtor rather than liquidation. ${ }^{128}$ It is said that the time limit of section $70 \mathrm{~b}$ is in conflict with section 116(1), which authorizes rejection of executory contracts without time limit, thus giving the trustee greater freedom of action. ${ }^{129}$

Although the trustee in reorganization is not subject to the time limits of section $70 \mathrm{~b}$, he is subject to other requirements. Contracts in the public authority may not be rejected in a chapter $X$ proceeding. ${ }^{130} \mathrm{~A}$ plan of reorganization for a public utility must be approved by the appropriate state commission. ${ }^{131}$ In deciding whether to reject a lease, the trustee must also reckon with the rule that under chapters X to XII, the lessor may prove a claim for as much as three years' rent ${ }^{132}$ as opposed to one year in straight bankruptcy. ${ }^{133}$ Finally, there is some authority that

126 Smith v. Hoboken R.R., Warehouse \& S.S. Connecting Co., 328 U.S. 123 (1946) (\$ 77); Finn v. Meighan, 325 U.S. 300, 840 (1945) (ch. X); Ghoti Estates v. Freda's Capri Restaurant, 332 Mass. 17, 123 N.E.2d 232 (1954) (provision for bankruptcy or receivership held to cover ch. XI arrangement). Contra, In re Burke, 76 F. Supp. 5 (S.D. Cal. 1948) (provision for bankruptcy or general assignment does not cover ch. XI).

127 The original proposal of the National Bankruptcy Conference included a provision that would have excluded $\S 70 \mathrm{~b}$ from applying to the other chapters, HaNNA \& McLachlan, The Bankruptcy Act 109 (6th ed. 1957). These provisions were evidently eliminated later as being too controversial.

128 Title Ins. \& Guar. Co. v. Hart, I60 F.2d 961 (9th Cir.), cert. denied, 332 U.S. 761 (1947); In re M \& S Amusement Enterprises, Inc., 122 F. Supp. 364 (D. Del. 1954) (debtor in possession under ch. X); In re Childs Co., 64 F. Supp. 282 (S.D.N.Y. 1944); In re Rochester Shipbuilding Corp., 32 F. Supp. 98 (W.D.N.Y. 1940). But cf. In re Forgee Metal Prods., Inc., 229 F.2d 799 (3d Cir. 1956) (court assumed without discussion that sixty-day limit applies in ch. $\mathrm{X}$, but held that trustee rejected contract by failing to notify other party).

129 Title Ins. \& Guar. Co. v. Hart, 160 F.2d 961, 965 (9th Cir.), cert. denied, 332 U.S. 761 (1947); cf. In re M \& S Amusement Enterprises, Inc., 122 F. Supp. 354 (D. Del. 1954); In re Childs Co., 64 F. Supp. 282 (S.D.N.Y. 1944). See text accompanying notes 113-16 supra.

130. Bankruptcy Act § 116(1), 52 Stat. 885 (1938), 11 U.S.C. § 516(1) (1958). See note 76 supra.

131 Bankruptcy Act $\$ 177,178,52$ Stat. 891 (1938), 11 U.S.C. $\$ \S 577,578$ (1958).

132 Bankruptcy Act $\S \S 202,353,458,52$ Stat. 893, 910, 921 (1938), 11 U.S.C. $\S \S 602,753$, 858 (1958).

133 Bankruptcy Act § 63a(9), 52 Stat. 873 (1938), 11 U.S.C. § 103(a)(9) (1958). See Gleick, Rent Claims and Security Deposits in Bankruptcy, 18 Mo. L. REv. 1 (1953), also 
rejection in a plan of reorganization ${ }^{134}$ must satisfy a test of good business judgment. This test has been most fully expounded in a railroad reorganization case. ${ }^{135}$ No court has held that the business judgment test applies in reorganizations under chapter $\mathrm{X}$, but there is some support for this view in both America ${ }^{136}$ and England.137 Such a test is desirable as a check upon arbitrary or unwise rejection by a trustee, yet it allows him considerable latitude.

\section{Concluston}

The major point of uncertainty in the law of rejection is the meaning of the lessor provision in section $70 \mathrm{~b}$ of the Bankruptcy Act. Congress should clarify this provision by adding a sentence stating that it applies to all real and personal covenants as defined by state law. This is the broad interpretation of the present clause. As a less desirable alternative providing somewhat less protection to lessees, the amendment should provide that the lessee is to have the benefit of all real covenants and that if the lease is to be rejected, the court should make appropriate orders protecting the lessee who has made valuable improvements to the premises. ${ }^{138}$ If the lessee is to continue in possession, the modification

appearing in 58 Com. L.J. 181 (1953), 27 ReF. J. 43 (1953); Newman, Rent Claims in Bankruptcy and Corporate Reorganization, 43 Colum. L. REv. 317 (1943).

134 It will be recalled that under chapters $\mathrm{X}$ to XIII the trustee has two chances to reject, once at the beginning and again in the plan of reorganization or arrangement. Bankruptcy Act $\S 116(1), 216(4), 313(1), 357(2), 413(1), 461(4), 613(1), 646(6)$, 52 Stat. 885, 895, 906, 910, 917, 921, 931, 934 (1938), 11 U.S.C. \$§ 516(1), 616(4), 713(1), 757(2), $813(1), 861(4), 1013(1), 1046(6)$ (1958). See text at note 28 supra.

135 Group of Institutional Investors v. Chicago, M., St. P. \& Pac. R.R., 318 U.S. 523, 549-5I (1943). The test is the business judgment of the Interstate Commerce Commission, as limited by the public interest in railroad service. For application of this test in the former reorganization of the New Haven Railroad, see Palmer v. Webster \& Atlas Nat'l Bank, 312 U.S. 156 (1941); Old Colony Bondholders v. New York, N.H. \& H.R.R., 161 F.2d 413 (2d Cir.), cert. denied, 331 U.S. 859 (1947); Badenhausen v. Guaranty Trust Co., 145 F.2d 40 (2d Cir. 1945) (sections five and seven of opinion); In re New York, N.H. \& H.R.R., 54 F. Supp. 595, 619, 621-28 (D. Conn. 1943); New York, N.H. \& H.R.R. Reorganization, 261 I.C.C. 195 (1945).

136 Harrigan v. Gilchrist, 121 Wis. 127, 352-53, 99 N.W. 909, 978 (1904) (receivership -contracts of manufacturer);。6 CoLlIER, BANKRUPTCY 685 (Moore \& Oglebay eds. 1947).

137 In re Newdigate Colliery, Ltd, [1912] $1 \mathrm{Ch} .468$ (court forbade receiver to reject contracts for delivery of coal because, inter alia, this would injure the good will of the business); cf. In re Thames Ironworks, Shipbuilding \& Eng'r Co., Weekly N. 66 (Ch. 1912) (receiver could properly reject contract to build ships because debtor could not possibly have any equity in the proceeds); In re Great Cobar, Ltd., [1915] 1 Ch. 682 (receiver was permitted to disaffirm contract establishing sole agents since this would not affect good will).

138 The British act authorizes the court to "make such orders with respect to fixtures, tenant's improvements, and to other matters arising out of the tenancy, as the court thinks just." Bankruptcy Act, 1914, 4 \& 5 Geo. 5, c. 59, § 54(3). 
of the terms of his lease should be commensurate with the treatment of secured creditors rather than common creditors.

Two other matters ought to be clarified by amendment to the Bankruptcy Act. Protection should be afforded the sublessee who is willing to assume the obligations of the head lessee upon that party's bankruptcy. ${ }^{138}$ And Congress should specifically provide that the time limits of section $70 \mathrm{~b}$ do not apply to proceedings under chapters $\mathrm{X}$ to XIII.

These three amendments would resolve most of the present uncertainties in the law. Until they are enacted, however, the prudent attorney for a lessee would do well to insert language in the lease to protect the lessee in event of bankruptcy or reorganization of the lessor.

139 See the British Act, supra note 138, § 54(6). 